\title{
AZ ÖNKORMÁNYZATOK SZEREPE A REGIONÁLIS REPÜLŐTEREK FEJLESZTÉSÉBEN
}

\author{
(The Responsibility of Local Government at the \\ Regional Airport Development)
}

\author{
TIBOLDI TIBOR
}

Kulcsszavak:

regionális repülötér fejlesztés önkormányzatok koordináció regionális fejlödés privatizáció piac kudarca

A Tér és Társadalom cimü folyóirat XXI. évfolyam 3. számában közölte Hegyi Fatime Barbara publikációját "Marketingorientált városfejlesztés" címmel. Jelen irásunkkal csatlakozni szeretnénk a megjelent írás tartalmához, valamint tovább erösiteni az önkormányzati szerep elötérbe kerïlését az infrastrukturális városfejlesztés, így a regionális repülöterek fejlesztése során. A tanulmány különleges aktualitását a korábbiakban egyértelmüen sikertörténetnek vélt FlyBalaton repülőtér 2008 öszén történt bezárása adja, mely példa rámutat a regionális repülöterek privatizációja, valamint az önkormányzati és a kalandor tỏke szerepének átgondolására.

\section{Elöszó}

A regionális repülötereket elsỏsorban az alacsonyabb utasszám különbözteti meg a nagyobb repülőterektől, amint ezt Kramer (1990) is megállapítja. Az utasszám növekedésének hátterében a régió növekedése áll, amely egyértelmúen közepes méretü, másodlagos nemzetközi repülőtérré emeli a regionális repülőtereket. A regionális repülöterek további sajátossága a menetrend szerinti forgalomban elérhetỏ városok alacsony száma, s ezzel összefüggésben az átszálló utasforgalom $5 \%$ alatti aránya. Ellentétben azonban a több utast kiszolgáló repülöterektől, e repülőterek sokkal erősebb függóségi viszonyban vannak a régió gazdaságával, amely lehet akár turisztikai vagy gazdasági jellegú. Az előbbire jó példa a Sármellék/FlyBalaton repülötér, amely elsősorban a balatoni és hévízi turizmusnak köszönhette életben maradását, míg utóbbira a Temesvári repülőtér, amely a régió gazdasági növekedésének eredményeképpen került be - utasszám alapján - Európa tíz leggyorsabban növekvő közepes méretủ repülőterei közé ${ }^{1}$.

\section{A regionális repülőterek fejlesztésének alapproblémája}

A fejlesztés dilemmája abból ered, hogy a tulajdonlás és üzemeltetés (fejlesztés) materiális környezetben szemlélve eltéró pozíciókat alakíthat ki a piaci szereplők számára. A hazai példák egyértelmüen bebizonyitották, hogy az állami szféra a tulajdonláshoz ugyan rendelkezik megfelelö eszközökkel, azonban a fejlesztéshez már szükségszerü a magánszféra, ezen keresztül a magántulajdon bevonása. Elsősorban a liberalizáció hatására megjelenő külföldi légitársaságok révén egyre jobban felszerelt 
kisebb vidéki, regionális repülöterek élednek újjá vagy épülnek ki. A regionális repülöterek fejlödése azonban a hiányzó gazdasági háttér nélkül elképzelhetetlen, ezért értékelödik ismét fel a köztulajdon felett tulajdonosi jogokat gyakorló önkormányzatok felelössége.

\section{Légi közlekedési iparág és a régió gazdaságának kölcsönhatása}

Az utóbbi években a regionális repülöterek iránt megnövekedett érdeklődés elsősorban a légi közlekedés liberalizációjával és annak hatásával hozható összefüggésbe. A diszkont légitársaságok világszintủ terjeszkedésével együtt jár a menetrend bövülése, amely a potenciális célállomások folyamatos elemzésével jár együtt. Alapvetően tehát a regionális repülöterek piacát azok a diszkont légitársaságok alkothatják, amelyek menetrendszerinti forgalom beindítását képesek biztosítani. E tendencia és az abban rejlő üzleti megfontolások késztetik a magán- és állami töke összefogását az addig kihasználatlan ,régiós vagyontárgy” fejlesztésére.

A regionális repülötereknek költségeik fedezéséhez - Kelet-Európában - éves szinten legalább 350 000-400 000 utast kell kiszolgálni, amely eléréséhez napi szinten 3-4, átlagosan $80 \%$-os kihasználtsággal üzemelő, minimum 180 fös repülögépeket kell fogadniuk. Az e cél eléréséhez szükséges fejlesztéseket azonban csak akkor ajánlatos véghez-vinni, ha a regionális repülötér müködésével biztosítani tudja a beruházás megtérülését.

Az új, alacsony költségen múködö légitársaságok közel tíz év alatt a légi közlekedési szállítás korábbi résztvevöinek rovására növelni tudták piaci részesedésüket. A low-cost légitársaságoknak az európai légi közlekedési piac 16\%-os piaci részarányát sikerült megszerezniük 2006-ra2; a Deutsche Bank (2004) elemzése alapján 2010-ig piaci részarányukat 20-25\%-ra növelhetik. A nagyarányú növekedés pozitív hatással jár majd a légi közlekedési iparágra, tágabb értelemben az iparági növekedésből profitáló nemzetgazdaságokra.

A kihívás tehát az, hogy Európa - és azon belül Magyarország - ne maradjon ki ebböl a fejlődésböl. Legyen haszonélvezője, és a múlt példáin keresztül olyan szabályzórendszert és környezetet alakítson ki, amely lehetőséget biztosít az iparági vertikum valamely részén való bekapcsolódásra. A nemzeti vagyon céltudatos felhasználása során a magántőkét olyan arányban érdemes bevonni, hogy közben az ország fejlődése ne szenvedjen csorbát. Magyarország számára fontos, hogy kihasználja a légi közlekedés műszaki fejlődéséből adódó gazdasági lehetőségeket. E tartalékokat a légi közlekedés, a turizmus és a régiók fejlődése érdekében integrálni kell. A regionális fejlödéshez szükséges regionális repülöterek fejlesztéséhez azonban csak akkor érdemes állami forrásokat is hozzárendelni, ha a repülötér bizonyitani tudja életképességét, azaz rendelkezik a regionális repülöterek gazdaságos üzemeltetéséhez szükséges feltételekkel.

Magyarország esetében a repülőterek fejlesztése az állam alacsony szerepvállalása mellett történhet (Új Magyarország... 2006). Eközben Európa nyugati felében tudatos, országok közötti koordináció eredménye a repülőterek fejlesztése, melyhez az 
egyes régiók jelentösen hozzájárulnak. Hazánk esetében megállapitható, hogy a történelmi regionális központok (Temesvár, Kassa, Zágráb) jelenlegi határokon kivülre való kerülésével valós, életképes régiókkal nem rendelkezik országunk. Ezért érdemes az ezen több száz éves fejlödés során kialakult centrumokkal való együttmüködésben keresni a régiók felzárkózását és integrálását, mint egy eröltetett saját regionális repülötérrel rendelkezó fejlesztésben. Erre vonatkozóan számos európai példa áll rendelkezésre, többek között a düsseldorfi repülötér, melynek vonzáskörzetébe Hollandia délkeleti részei is beletartoznak. E tekintetben emlitésre érdemes még Stuttgart, Trieszt és a bécsi repülötér is, melyek hasonlóan magas „,külföldi" részarányú érkezö-induló forgalommal rendelkeznek. A monarchia korábbi regionális központjainak többsége jelenleg is centrumként funkcionál, és regionális repülöterei is jelentös fejlödéseken mentek keresziül. Ezért a Kárpát-medence regionális repülöterei és környezö városai között a közlekedési lehetöségek fejlesztésére kell nagyobb hangsúlyt forditani, így a vasút, buszjáratok kiszámithatóságára, közutak fejlesztésére.

Nagy dilemmát okoz minden regionális repülötérnek, hogyan tudnak kitörni az ad hoc járatok kiszolgálásából és elérni a menetrend szerinti járatok megszerzését. A repülöteret tulajdonló, üzemeltetó cégek vezetőivel, önkormányzati tisztségviselöivel folytatott interjúink során egyaránt az alacsony költségü légitársaságok menetrend szerinti forgalmában látják a kitörési lehetóségeket. E nézeteinket támasztották alá Békéscsaba, Debrecen, Györ, Pécs, Sármellék, Veszprém repülötereinek fejlesztéséért felelö vezetöi is.

\section{A regionális repülöterek fejlesztésének nemzetközi gyakorlata}

A regionális repülöterek magánositásának azért van meghatározó jelentösége, mert mint a régiókban található vagyontárgy, a régió fejlesztésének érdekében azzal szoros összefüggésben fejti ki tevékenységét, elsösorban regionális érdekeket szolgálva. Ettől eltérő, ha a régióban lévő repülötér nem polgári, hanem katonai, ugyanis ekkor közérdeket szolgál.

A tanulmány keretében vizsgált föderalista berendezkedésủ németországi és ausztriai regionális repülóterek tulajdonlása és üzemeltetése struktúráának összefoglalását az 1. táblázat szemlélteti. A mindösszesen harminc vizsgált regionális repülótérböl három németországi és két magyarországi repülötér kivételével arra az eredményre jutottunk, hogy a regionális repülöterek tulajdonosi, üzemeltetési feladatait helyben, állami feladatként végzik. Ezzel szemben Anglia és Írország szinte teljes mértékben magánositotta regionális repülötereit.

Ennek egyik lehetséges oka, Horváth (2007) megállapitása alapján, hogy a föderalizált és a regionalizált berendezkedésủ országokban a mezoszint közigazgatási központjai tényleges régióközpontokként müködnek, a decentralizált és az unitárius országokban a NUTS2 egységek központjai korlátozott (tervezési, szervezési) funkciókkal rendelkeznek. Ennek ellensúlyozására és a regionális fejlödés meginditása érdekében a regionális repülöterek magánositása a régiók felzárkózásához vezethet. 


\begin{tabular}{|c|c|c|c|}
\hline \multicolumn{4}{|c|}{$\begin{array}{c}\text { 1. TÁBLÁZAT } \\
\text { A vizsgált regionális repülöterek tulajdonosi struktúrája } \\
\text { (Ownership Structure of the Analyzed Airport) }\end{array}$} \\
\hline & $\begin{array}{l}\text { A vizsgált } \\
\text { regionális } \\
\text { repülöterek } \\
\text { száma }\end{array}$ & $\begin{array}{l}\text { ebbỏl magántulaj- } \\
\text { donban lévő repü- } \\
\text { lötér és/vagy üze- } \\
\text { meltetés }\end{array}$ & $\begin{array}{c}\text { A magántulajdon- } \\
\text { ban lévö repülötér } \\
\text { és/vagy } \\
\text { üzemeltetés aránya }\end{array}$ \\
\hline Ausztria & 5 & 0 & 0 \\
\hline Magyarország & 8 & 2 & $25 \%$ \\
\hline Németország & 17 & 3 & $18 \%$ \\
\hline
\end{tabular}

Forrás: Saját gyüjtés alapján (2006).

Ausztria esetében valamennyi regionális repülőtér köztulajdonban van, azaz közvetlenül a város és megyei érdekeltségébe (Salzburg, Klagenfurt) tartozik, vagy a város érdekeltségébe tartozó vállalaton keresztül (Stadtwerke Graz) jelenik meg. Vizsgálataink egyértelmúen alátámasztják, hogy az osztrák regionális repülóterek az állami tulajdonlás ellenére nyereségesen üzemeltethetők. Mind Salzburg, mind Graz esetében milliós nagyságú volt 2005-ben a repülötér adózott eredménye (2,2 millió euró; 7,0 millió euró) köszönhetően a városokat körülvevó ipari és idegenforgalmi létesítményeknek, valamint az alacsony költségú légitársaságokra vonatkozó stratégiának.

Kétségtelen tény azonban, hogy a légi közlekedésen belül egyre inkább előtérbe kerül a hatékonyságnövelés, és ezen keresztül a költségek csökkentésének igénye, elsősorban a nagyobb repülőterek esetében. Elemzéseinkból kiderült, hogy a magántöke térnyerése elsösorban a közepes és nagyobb repülöterek esetében figyelhetö meg, miközben a kisebb regionális repülöterek a szövetségi berendezkedésü államokban egy-két kivételtöl eltekintve köztulajdonban maradnak. Ezt a tényt támasztja alá a Macquire-csoport és Hochtief vállalatok akvizíciós stratégiáért felelös munkatársaival készített interjúk eredménye is, mely során megállapítást nyert, hogy a repülöterekkel foglalkozó nagyobb befektetői csoportok felvásárlási érdeklődésének középpontjába a már müködő és legalább 5 millió utas/év forgalommal rendelkezö repülöterek kerülnek.

Természetesen mindkét - a regionális repülöterek magánkézbe adására és a nagyobb repülöterek köztulajdonban való megtartására is - találunk példákat. Az elóbbire a Lübecki repülőteret képviselö testület egy kisebb, 600000 utas/év forgalmú repülöteret üzemeltetö városi tulajdonban lévő társaságát értékesítette $90 \%$-ban az új-zélandi Infratil-csoportnak. A befektető a 13 millió eurós vételi ár mellett 60 millió euró fejlesztési kötelezettséget is vállalt.

A 2. táblázat mutatja, hogy a nagyobb európai repülőterek közül mindezidáig melyek nem kerültek magántulajdonba (Fluggastverkehr... 2007). 
Tiboldi Tibor : Az önkormányzatok szerepe a regionális repülöterek fejlesztésében.

Tér és Társadalom 22. évf. 2008/4. 135-148. p.

TÉT XXII. évf. 2008 - 4

Gyors ténykép

139

2. TÁBLÁZAT

A nem magántulajdonban lévö nagyobb európai repülōterek utasforgalma (Passanger-traffic of the Major European Non-private Airport)

\begin{tabular}{lccc}
\hline \multirow{2}{*}{ Repülötér } & \multicolumn{2}{c}{ Utasforgalom (millió utas) } & \multirow{2}{*}{ Változás (\%) } \\
\cline { 2 - 3 } & 2006 & 2007 & \\
\cline { 2 - 3 } Paris (CDG) & 56,4 & 59,9 & 6,2 \\
Amsterdam (AMS) & 45,9 & 47,7 & 3,9 \\
München (MUC) & 30,6 & 33,9 & \\
\hline
\end{tabular}

Forrás: www.aci.com

A regionális repülőterek esetében már nem lehet egyértelmủen kategorizálni az egyes országokat azok regionális repülőterekre vonatkozó tulajdonosi struktúrája alapján. Ugyanis, amint azt Ausztria példája is megmutatta, a bécsi repülötér magántulajdona nem jelenti automatikusan az osztrák regionális repülöterek magánosítását, de a megállapítás fordítva is igaz, a franciaországi fö repülőterek állami tulajdona mellett egyre inkább megjelennek a magántulajdonban lévő regionális repülőterek, így például a Grenoble-i repülötér, amelyet 2004. január 1-jén került magántulajdonba. Meg kell emliteni az angolszász országok - azon belül is elsösorban USA, Anglia és Írország - példáit, ahol a regionális repülötér-fejlesztés számos esetben magántökéböl valósul meg. Ennek oka kettös: a verseny magasabb érettségi foka és a tradicionálisan kisebb regionális piacszabályzó szerep. Ugyanis, amíg a légi közlekedési verseny hasonlóan magas szinten áll Németország vagy Spanyolország piacain (elöbbi 2006-ban 154 milliós utasszámával és $21 \%$-os piaci részesedéssel az EU27 második legnagyobb piaca volt, Spanyolország esetében 150 millió utasról és 20\%-os piaci részesedésről beszélhetünk), addig e két országra jellemzö paternalista állami szemlélet kevésbé engedett befolyást a magántökének a regionális repülöterek fejlesztésében.

\section{Az önkormányzati és magántőke kombinációjának lehetséges optimumai}

Egyéni kutatásaink alapján - amelyeket az európai regionális repülöterek tulajdonosi szerkezetére vonatkozóan végeztünk - megállapitható, hogy a regionális repülöterek akkor tudják a régióval való kölcsönhatásukban vállalt szerepüket leginkább betölteni, ha a magán- és állami tulajdon aránya nem tolódik el jelentösen egyik fél számára sem (1. ábra). Ugyanis a magas magántőkével létrejött regionális repülötér üzemeltetésének elsődleges célja a profit maximalizálása és nem a régióval való aktív együttmüködés, ezzel szemben a magas állami töke mellett létrejött regionális repülöterek a szükséges fejlesztésekhez már nem tudnak pénzeszközöket mozgósítani, valamint a repülőterek menedzsment feladatait sem tudják megfelelően ellátni. 
Tiboldi Tibor : Az önkormányzatok szerepe a regionális repülöterek fejlesztésében.

Tér és Társadalom 22. évf. 2008/4. 135-148. p.

\section{1. ÁBRA}

A társadalmi összhaszon alakulása az eltérô tőkeszerkezettel megvalósitott regionális repülótérfejlesztés mellett (nemzetközi példák) (Changes of Social Profit Contribution of Regional Airport Development at Different Capital Structure)

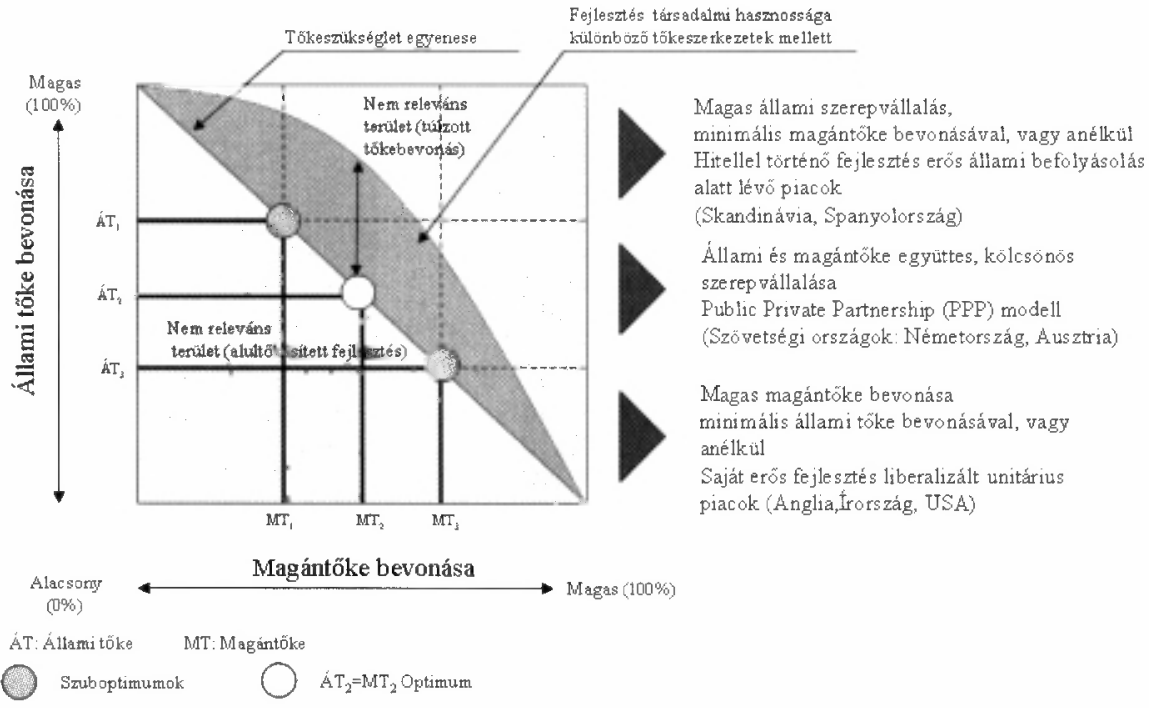

Forrás: Saját számítás és szerkesztés.

Mindkét szélső érték, azaz túlzott mértékủ magántőke (MT) vagy állami tőke (ÁT) bevonása elvezethet a regionális repülötér megszüntetéséhez vagy ideiglenes bezárásához. Erre vonatkozóan példával szolgál a debreceni, a pécsi regionális repülötér, melyek már évek óta képtelenek megfelelő arányú magántőke bevonására az üzemeltetéshez.

Egy elméleti optimumhoz közeli állapotnak az a tökekombináció felelhet meg, amelyben közel azonos arányban vesz részt az állami és a magántöke. Ebben az esetben lehet az elméleti szintủ társadalmi haszon maximális.

Számos fejlett ország, így Németország esetében is az elkövetkező évtizedben a regionális repülöterek magánosításának elsö lépése lehet a magántőke és az állami tőke részarányának kiegyenlítése. A kelet-európai országok esetében a repülőtérfejlesztések kapesán a lehetö legjobb megoldást és optimumot jelentheti e gyakorlat alkalmazása. Figyelembe kell azonban venni a tőke eredetét is, ugyanis a multinacionális tőke érdeke jelentösen eltérő lehet a hazai magántőkétől. Ezért a repülöterek magán és állami tőkével való együttes fejlesztése során minden esetben célszerủ e vizsgálatot is elvégezni. Az önkormányzatok számára fontos a helyi fejlődés kontrollja, a fejlesztési irányok ellenőrzése, a foglalkoztatottsági kérdések egyensúlyban tartása. A fejlesztések megvalósulási formája sok esetben a köz- és magánszféra közös fellépése (Public Private Partnership), ahol az állami és közszféra, a magánszektor és a hitelezők is megtalálják motivációjukat a repülőtér-fejlesztés során. 
Tiboldi Tibor : Az önkormányzatok szerepe a regionális repülőterek fejlesztésében.

Tér és Társadalom 22. évf. 2008/4. 135-148. p.

TÉT XXII. évf. 2008 - 4

Gyors ténykép

Elsősorban Németországban találhatunk számos jól müködő példát a regionális és nagy nemzetközi repülőterek közös állami és magántőkéből való fejlesztésére. Magyarország esetében a jogi bizonytalanságok kapcsán a PPP modell sok esetben a magántőkét kedvezőbb helyzetbe hozza az állami- és közszféra jelentös és tartós elkötelezettsége mellett.

\section{A repülötér-fejlesztés makroökonómiai és mikroökonómiai hatásai}

A regionális repülőterek és jövedelmi változások közötti vizsgálatot a régió és repülótér összefüggéseinek vizsgálatával kezdjük. A 2. ábra mutatja, hogy a regionális fejlesztés alapvetően három fő pillérre épül: a természeti eröforrásokra, az infrastruktúra é és a politikai és adminisztratív struktúrára.

\section{2. ÁBRA}

A regionális repülötér fejlesztésének feltételrendszere (Preconditions and Complexity of Regional Airport Development)

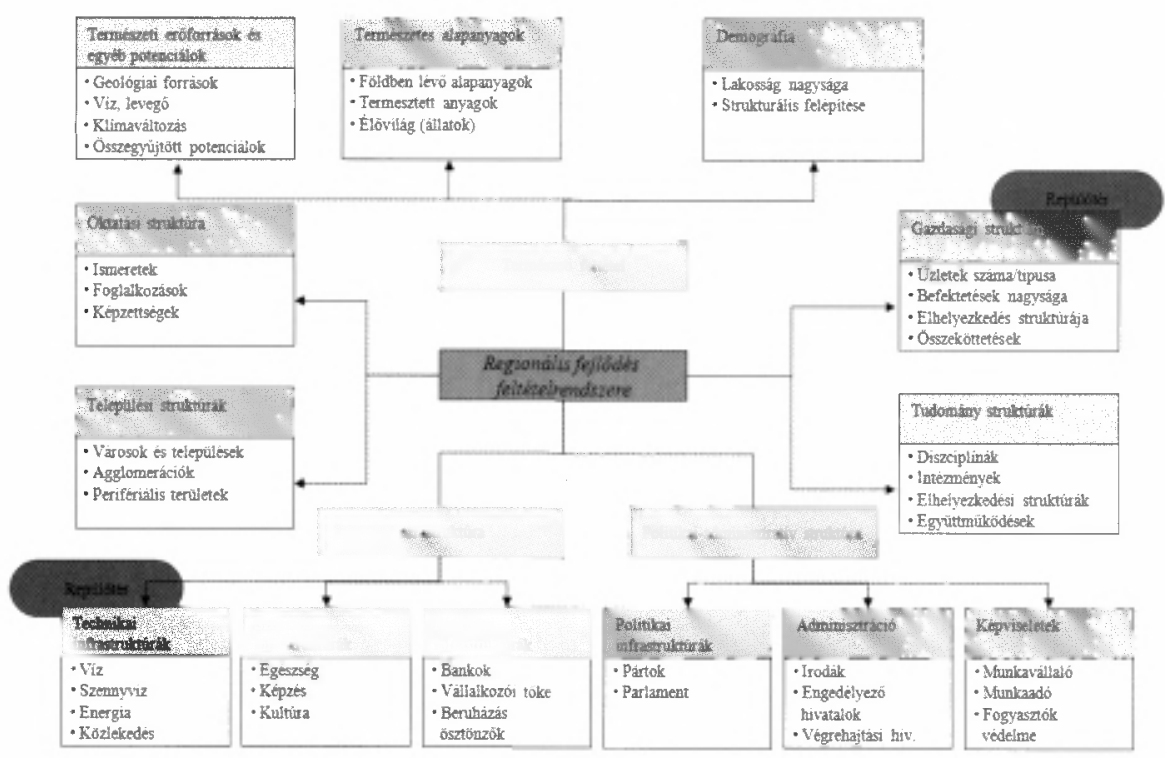

Forrás: Component 3 of the EARD Project... (2006).

A regionális repülőterek fejlesztésének vizsgálatát minden esetben e három elem alapos vizsgálatával kell kezdeni, de nem kerülhető meg a további négy tényezỏ - a képzési rendszer, a települési struktúra, a gazdasági struktúra és a tudományos struktúrák - vizsgálata sem. Régió és repülötér kapcsolata két esetben triviális: ha a régió technikai infrastruktúráit elemezzük, illetve amikor a régió gazdasági elönyeit vesszük számba. 
A repülöterek elemzése kapcsán megállapitjuk, hogy push és pull fejlödési stratégiát lehet megkülönböztetni attól függően, hogy a régió és a repülötér fejlettségi szintje milyen kapcsolatban áll egymással.

Ezt az összefüggést fejezi ki a régió és a repülötér innovációs mátrixa. A mátrix egyik tengelyén a regionális repülötér innovációs kínálati potenciálja helyezkedik el, amely az alacsony és a magas értékek között váltożhat. A másik tengelyén pedig a régió innovációs kínálata található, amely szintén az alacsony és a magas értékek között veheti fel értékeit. A mátrixban négy pozíciót különböztetünk meg, melyböl az optimális helyzet a regionális repülötér és a régiók fejlesztésére nézve akkor jelentkezik, ha egyszerre érvényesül a régiók innovációs magas kereslete és a magas repülőtéri innovációs kínálati potenciál (3. ábra).

\section{3. ÁBRA}

A régió és repülötér innovációjának összefüggése

(Development Contiguity between Region and Airport)

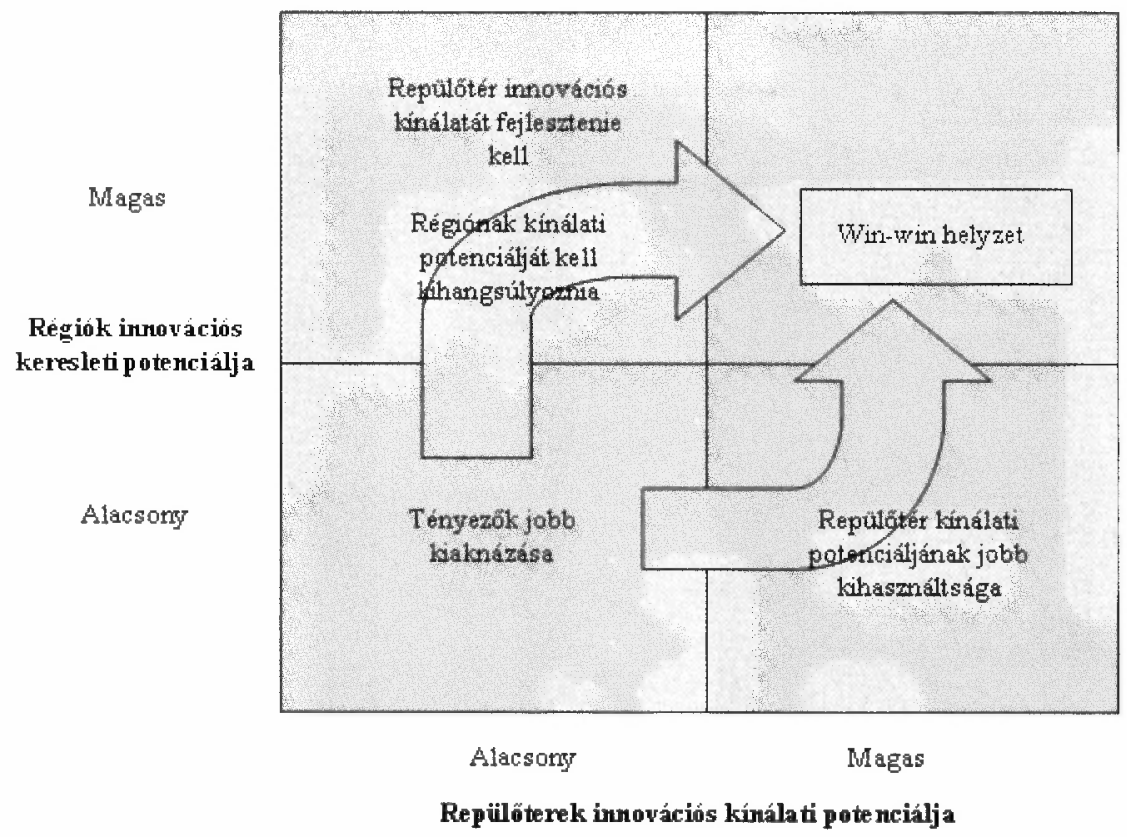

Forrás: Component 3 of the EARD Project... (2006).

Ebben az esetben fejlỏdő, jól prosperáló régióról van szó, amelyet folyamatos fejlesztési prés jellemez, és ezzel egyidejủleg a repülötér innovációs kínálata is magas. Ez azt jeleni, hogy technikailag és a szolgáltatások kínálatával egyaránt ki tudja szolgálni azokat az utas-szállítási vagy áruszállítási igényeket, amelyek azért jelentkeznek, mert a régió iránti érdeklődés megnövekedett. Ebben az esetben beszélünk mindkét szereplő számára optimális (win-win) állapotról. 
Amennyiben a két tényező valamelyike - régió és a régió repülőtere - nem rendelkezik azokkal az ismérvekkel, amelyek az innovációs keresleti potenciál (régió) vagy a kínálati potenciál (repülőtér) magas szintjét lehetővé teszik, akkor a helyzet nem optimális.

A szóban forgó egyensúlyi állapot a makrogazdasági politika feladata. Az önkormányzati politika céljai között feltétlenül szerepelnie kell az innováció ösztönzésének, amely kedvezőbb beruházási környezetet igényel és elvezet a szóban forgó optimális állapotba (win-win helyzet). Véleményünk szerint a közszférának is érdeke a regionális repülötér beruházásokban való részvétel, hiszen gazdaság élénkitö hatásaiból az önkormányzat saját maga is részesedik.

Meg kell vizsgálni azt az esetet is, ha a régió innovációs kereslete magas, de a repülőtér innovációs kínálata alacsony (pull). Ez az eset jellemző leginkább a keleteurópai országok regionális fejlödésére, hiszen a régió fejlődése elöbb következett be, mint a repülőtér fejlődése. A hazai példák többsége, így például Győr-Pér, PécsPogány, Sármellék/FlyBalaton példái is ebbe a kategóriába esnek. Tapasztalataink egyértelmủen alátámasztják az önkormányzati politika ezen helyzetben való aktív megnyilvánulását, azonban az önkormányzatok csak a lehetöségeikhez képest tudtak a regionális repülőterek innovációs kínálatának növekedéséhez hozzájárulni. Nemzetközi - elsősorban német és osztrák - példák alapján megállapítható, hogy azok az önkormányzatok jártak el helyesen, amelyek nem vonultak ki teljesen a regionális repülöterek fejlesztéséböl, hanem aktív részesei voltak a repülöterek innovációs kinálatának fejlesztésében. Támogatásukkal ugyanis hozzájárultak a régióba érkezỏ utasforgalom növeléséhez, valamint fejlesztési források bevonásával logisztikai központok kialakításába is belekezdtek. A helyi önkormányzati kontroll ugyanis katalizátorként is működhet, árszabályozási kérdésekben pedig támogathat olyan politikát is, amely rövid távon nem a nyereség növelését, hanem a régió fejlödését helyezi elötérbe.

Amennyiben elöbb a repülỏtér alakul ki és ennek hatására indul el a régió fejlődése push fejlödési stratégiáról beszélhetünk.

A regionális repülöterek makroökonómiai hatását összefoglalva elmondható, hogy a régióban realizálódó jövedelmet jelentösen növeli a regionális repülötérfejlesztése. $A z A C I$ (2004) jelentése 59 európai repülötéren végzett felmérésre alapozva megállapitja, hogy szoros összefüggés fedezhetö fel az utasszám és a foglalkoztatottság között. Ennek értelmében minden 1 milliỏ utas után 1000 új munkahely jön létre közvetlenül a repülōtéren, valamint 2100 munkahely nemzeti szinten és további 1600 munkahely a régióban (www.aci.com). A munkanélküliség csökken, hiszen növekszik a kereslet a munkaerö iránt, javul a régióban a szolgáltatások minösége is, amely megtartó erőt képvisel a képzett lakosság körében. A regionális versenyképesség, a mobilitás vagy az európai kulturális és gazdasági integráció által lehetővé tett nemzetközi mobilitás oda-vissza irányuló folyamata szintén a regionális jövedelmek emelkedéséhez vezet. A regionális repülöterek a régióra gyakorolt hatásukat helyben fejtik ki, azaz a helyi önkormányzati politika nem állhat tétlenül a repülỏtér-fejlesztés kapcsán, hiszen a repülótér és a régió közösen profitál a repülőtér fejlesztéséből. 
A makrogazdasági hatás mérésére Keynes megközelítése a legalkalmasabb, melyet a regionális gazdaságtannal foglalkozó szakemberek is (Lengyel-Rechnitzer 2004) a regionális jövedelem mérésére használnak.

A képlet:

$$
\begin{gathered}
Y=C+G+I+(X-M) \text {, ahol: } \\
Y=\text { reáljövedelem, } C=\text { fogyasztás, } G=\text { kormányzati kiadás, } \\
I=\text { beruházás, } X=\text { export }, M=\text { import. }
\end{gathered}
$$

Ennek alapján a régióban keletkező jövedelemre a fogyasztás, a kormányzati kiadás, a beruházás és az export-import egyenlege hat. Az említett alapvető makroökonómiai összefüggésből megállapítható, hogy a régióban keletkező reáljövedelem (Y) növekedéséhez egy regionális repülötér aktívan hozzá tud járulni a régióban keletkezö - beérkezó turisták, üzleti utasforgalom által létrejött - pótlólagos fogyasztás (C) során. A kormányzati kiadásoknak (G) akkor van kitüntetett szerepük, ha a repülötér létrejöttével állami beruházás is megvalósul úgy, mint például az infrastruktúra kiépítése. A beruházások (1) értelemszerúen szükséges velejárói egy regionális repülőtér-fejlesztésnek, hiszen a repülötér felépitése, bővítése és korszerúsítése beruházást von maga után, amely a régióban marad, s elsôsorban a régióból származó inputokra épít. Végezetül az export és import egyenlege a repülötér múködéséböl származóan olyan reáljövedelmet befolyásoló tételeket takar, mint a repülötér tevékenységével összefüggő export (X) és import $(\mathrm{M})$. Ide tartoznak például azok az export termékek és szolgáltatások, amelyek külföldre kerülnek értékesítésre (például más légitársaság számára) és azok az importált javak, amelyek a repülötéren vagy a régióban kerülnek felhasználásra. Az általunk végzett felmérés eredménye is igazolja a feltételezést, miszerint a regionális repülötér müködése által keletkezett utasforgalomból származó jövedelem a régióban marad.

A mikroökonómia - szemben a makroökonómiával - nem aggregáltan vizsgálja a gazdaság szereplöit, hanem külön-külön, egy adott környezetbe helyezve azokat. A vizsgálat érdekében egy ötszereplős modellt vezetünk be, melyet az 4. ábra mutat.

A régióba a repülötéren keresztül érkező utasok a különböző szolgáltatások igénybevétele, vagy a közjavak fogyasztása során kapcsolatba kerülnek az önkormányzattal, a repülőtérrel, a vállalati szegmenssel és a helyi lakossággal is. Abban az esetben, ha az önkormányzat függetleníti magát a 4. ábrán jelzett szolgáltatásigénybevételifolyamattól, és semmilyen ösztönző, szabályzó, esetleg piacregulátori szerepet nem vállal, a régióba érkezó utasok kisebb hasznosságérzettel távoznak.

Ez az állitás azzal indokolható, hogy Magyarországon szükséges a piacszabályozás azon formája, melyben a helyi önkormányzatok azokat a feladatokat is ellátják, amelyekre a magántöke nem, vagy csak olyan profitráta mellett vállalkozik, amely kárositja a fogyasztókat. A 4. ábrán folytonos nyíl jelenti a repülötérre érkező utasok kapcsolatrendszerét. 
Tiboldi Tibor : Az önkormányzatok szerepe a regionális repülöterek fejlesztésében.

Tér és Társadalom 22. évf. 2008/4. 135-148. p.

\section{4. ÁBRA}

A regionális repülötér mikrokörnyezete

(Macroeconomic Environment of Regional Airport)

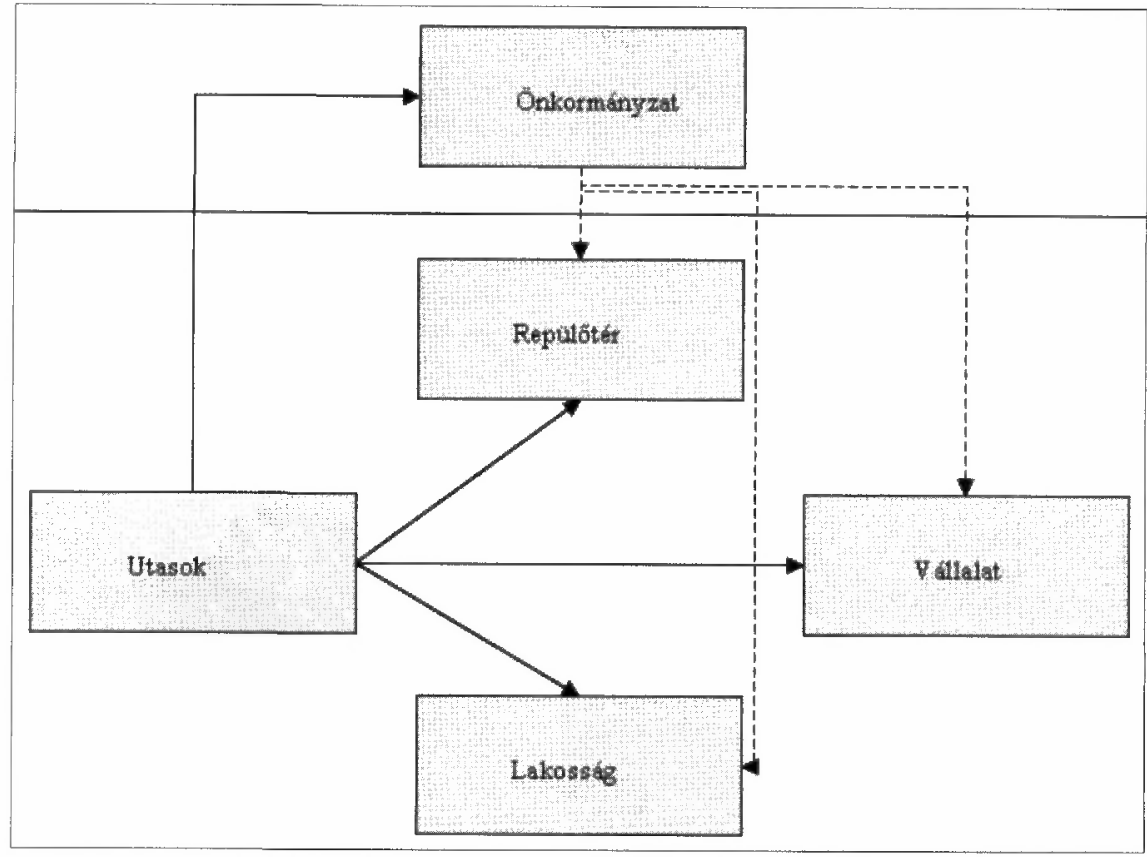

Forrás: Saját szerkesztés.

Az utasok szolgáltatásokat vesznek igénybe a repülỏtértől, a vállalati szegmenstöl, a lakosságtól, valamint a helyi önkormányzatoktól is. Tisztán piacgazdasági (tökéletes verseny) feltételek között a szolgáltatások piaci ára egy kompetitív ár. Azonban sok esetben a kisebb fejlesztés alatt lévő regionális repülötereknél hiányzik a méretgazdaságosság, azaz a vállalati szektor nem piacosítja szolgáltatásait, amelyekre az utasok részéröl piaci kereslet jelentkezne. Ekkor van arra szükség, hogy az önkormányzat beavatkozzon a piacgazdasági folyamatokba (a 4. ábrán a szaggatott vonallal jelölt kapcsolat), és átvegye, vagy kikényszerítse azokat a szolgáltatásokat, amelyeket a magántőke az említett okoknál fogva nem végez el. Erre jó oka van, hiszen mikroszinten az egyes utasok által jelentkező kereslet kiszolgálói elsődlegesen a repülötér, a vállalat és a lakossági szegmens lesznek.

Amennyiben a régióba érkező utasok nem kapják meg az elvárt szolgáltatásokat, vagy csak a piaci árnál magasabb áron, akkor csalódottan fognak távozni, végső soron az utasok a régiót túlértékeltnek tekintik, melynek következménye a csökkenö utasszám és a csökkenő árbevétel lesz. Tapasztalataink alapján az önkormányzat nem tud olyan hatékony ösztönzöt és ezzel együtt járó kontrollt kialakítani, amely alapján kevesebb eröforrásból hatékonyan látná el a kompetitiv szolgáltatásokat, ezért e feladatokat a magántökével társulva közösen sikeresen végezheti. 
Tiboldi Tibor : Az önkormányzatok szerepe a regionális repülőterek fejlesztésében.

Tér és Társadalom 22. évf. 2008/4. 135-148. p.

A makro- és mikoökonómiai hatásokat Graham (2001) kutatása alapján közös ábrában bemutatva látható, hogy legföképpen a követlen és a katalizátor hatások hatnak az adóbevételekre a közvetett és indukált hatásokon keresztül (5. ábra).

\section{5. ÁBRA}

A repülötér közgazdasági hatása

(Airports' Economic Effect)

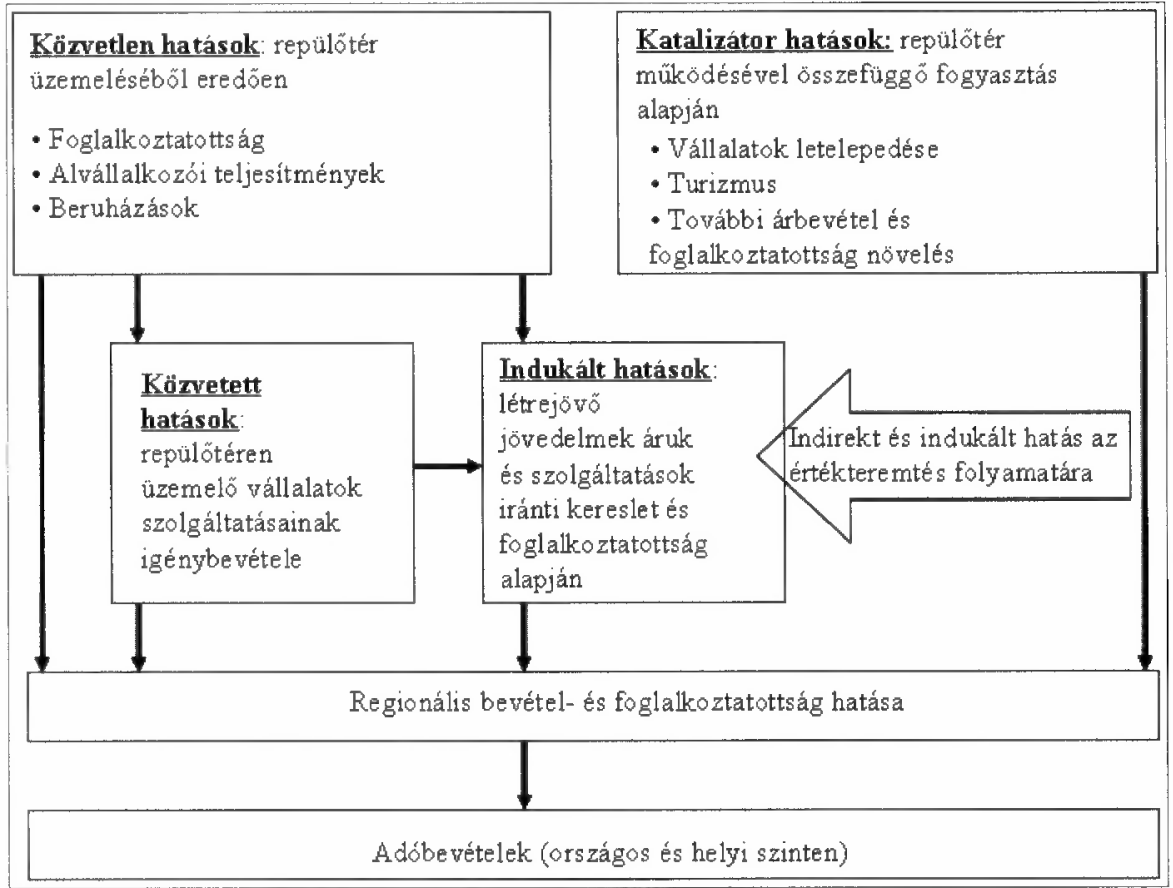

Forrás: Graham (2001).

Egyetértünk Klophaus (2006) megállapításával, miszerint a közvetlen, a közvetett és az indukált hatások eredője a repülőtéri tevékenységek, szolgáltatások. Ezzel szemben a katalizátorhatás alatt a régió egyszerủbb és jobb elérhetőségét értjük, amely a légi közlekedés müködésének eredményeképpen jön létre. Ebböl következöen a katalizátorhatás csak abban az esetben fejti ki hatását, ha a repülötér üzemel, tényleges hatását pedig csak abban az esetben, ha a forgalom menetrendszerü, melyre a betelepült vállalatok is tudnak épiteni. E megállapitást Erdösi (1999) úgy fogalmazza meg, hogy a regionális repülóterek jelentósége nem annyira a foglalkoztatottságban és a bevételi hatásokban, hanem sokkal inkább a telephely funkcióban nyilvánul meg.

A repülötér üzemelése további vállalatokat vonz magával, ami a foglalkoztatottság növelésével jảr együtt, azaz munkahelyteremtỏ beruházássá válik, növelve ez által a város adóbevételeit (mérhetó pozitiv externáliák). Magyarország esetében az Audi telephelyválasztását nagyban befolyásolta a meglévö péri repülötér, melynek 
további fejlesztését nagyrészt az Audi biztositotta. A kezdetben motorgyártással foglalkozó német vállalat megjelenése további beszállítók megjelenését vonta maga után. A péri repülőtér adatnyilvántartása szerint a meglévő utasforgalom a nyári charterforgalom kivételével szinte kizárólag az Audi németországi központja, Ingolstadt és a győri gyár közötti üzleti forgalmat jelenti. Az Audi a péri repülőtér kiépítése kapcsán már korábban kinyilvánította maximális támogatását, mely kapcsán 2002 és 2003 között egymillió euró értékben támogatta a jelenlegi repülötéri infrastruktúra kiépítését.

Minden bizonnyal az utolsó még önkormányzati tulajdonban lévő, valóban minden tekintetben kiváló adottságú Győr-péri repülőtér tulajdonos önkormányzatai a repülőtér fejlesztése előtt felismerik az önkormányzati kontroll tartós szükségességét, és a FlyBalaton magánosításának rossz tapasztalatait felhasználva valóban létrejöhet Magyarország első önkormányzati és magántulajdon által együttesen fejlesztett és üzemeltetett regionális repülőtere. Hazánk gazdasági helyzete ugyanis predesztinálja a fejlesztéshez és üzemeltetéshez a magántulajdon részvételét, azonban a nyugat-európai példák alapján a profitabilitásnak nem szükséges feltétele a regionális repülöterek teljes magánosítása.

\section{Összefoglalás}

Magyarország esetében a repülőterek fejlesztése az állam alacsony szerepvállalása mellett történik, mely stratégia az Új Magyarország Fejlesztési Terv-ben (2006) is megjelenik. Eközben Európa nyugati felében tudatos, országok közötti koordináció eredménye a repülőterek fejlesztése, melyhez az egyes régiók jelentősen hozzájárulnak. Hazánk esetében megállapítható, hogy az önkormányzatok jelenleg nem rendelkeznek a regionális repülőterek fejlesztéséhez szükséges erőforrással, stratégiával és szakértelemmel. Az átgondolt fejlesztési politika hiányában, számos esetben vállnak meg az önkormányzatok a régió vagyontárgyától - a regionális repülötértől -, lemondva így az önkormányzati kontrollról, amely számos nyugat-európai országban bizonyította létjogosultságát, hazánk esetében pedig a piac kudarcához vezetett. Ezért ajánlott a regionális repülőterek ,piaci kudarca” helyett a helyi önkormányzatok szerepének átgondoltabb részvételét ösztöözni a regionális repülőterek magánosítása során.

\section{Jegyzetek}

${ }^{1}$ A Temesvári repülötér 2005 és 2006 között 23\%-kal növelte utasszámát, 611 ezerröl 753 ezer före (Airport Timisoara 2007).

${ }^{2}$ Forrás: http://www.researchandmarkets.com/reports

${ }^{3} 2007$ decemberében nincs közvetlen vasúti összeköttetés Szeged-Temesvár között, annak ellenére, hogy e vonalat 1857-ben nyitották meg (MÁV Zrt). 


\section{Irodalom}

Airport Timisoara. (2007) http://aerotim.ro/en/despre/trafic/

Component 3 of the EARD Project: Strengthening of Economic Attractiveness within Airport Regions. (2006) Report from the exchange workshop „Sustainable regional development in new airport region” and the 5th project meeting. Spain, 9-10. November. INTERREG IIIC EAST EARD PROJEKT.

Erdősi F. (1999) Légi közlekedés és területi fejlödés. - Tér és Társadalom. 4. 45-76. o.

Fluggastverkehr in Europa im Jahr 2006. (2006) Eurostat. www.eurostat.com

Graham, A. (2001) Managing airports. Butterworth Heinemann, Oxford.

Horváth Gy. (2007) Regionális központok és regionális fejlödés. - Magyar Tudomány. 6. 704. o.

Klophaus, R. (2006) Volkswirtschaftliche Bedeutung von Regionalflughäfen und Verkehrslandeplätzen. Zentrum für Recht und Wirtschaft des Luftverkehrs, Berlin-Schönhagen.

Kramer, J. (1990) Luchthavens en hun uitsaling. Knag, Amsterdam.

Lengyel I.-Rechnitzer J. (2004) Regionális gazdaságtan. Dialóg Campus Kiadó, Budapest-Pécs. Perspectives of Low-Cost Carriers in Europe. (2004) Deutsche Bank. http://www.dbresearch.com Új Magyarország Fejlesztési Terv. (2006) Nemzeti Fejlesztési Ügynökség, Budapest. 